\title{
Impact of Rewards on Employee Motivation of the Telecommunication Industry of Bangladesh: An Empirical Study
}

\author{
Ayesha Binte Safiullah \\ ${ }^{l}$ (Business Studies, University of Information Technology and Science, Bangladesh)
}

\begin{abstract}
In the age of globalization organizations have realized the importance of their human resources and become increasingly interested in managing employees in such a way that can enhance business performance. To ensure competitive advantage, people who are working for the organization should be motivated by providing a well-balanced reward and benefit system. The purpose of this study is to identify the relationship between rewards (extrinsic and intrinsic) and their impact on employee performance and actions to motivate the employees of Telecommunication industry. The data was collected from 81 employees of different telecommunication companies and was analyzed using mean values and frequency percentage tables. The result concludes that, with the advancement in the career path, income level and age intrinsic rewards become the vital factor for the employee motivation. However, organizations should consider for a more structured reward system that considers both intrinsic and extrinsic rewards which in turn prospers high performance culture in the telecom industry.
\end{abstract}

Field of study: Human Resource Management.

\section{Introduction}

Human resource is considered as the most important asset of every organization. In the age of global competition, acquiring right workforce and retaining it becomes the most important challenge of all organizations. To get the maximum from these resources, employees must have to be motivated. Baron (1983) describes motivation as, "an accumulation of different processes which influence and direct our behavior to achieve some specific goal" [1].

The factors those act as motivators and affect employee performance are job security, working conditions, employer-employee relationship, autonomy, relationship with colleagues, training and development opportunities, employee recognition and company's overall policies and procedures for rewarding employees. Among all these factors, motivation that comes with rewards becomes important factor which increases the exceptional contribution by employees. As stated by Bowen (2000), in a world of downsizing, doing more with less, reward/recognition are vitally important to boost morale and creating goodwill between employees and managers [2].

Rewards can be extrinsic or intrinsic, extrinsic rewards are tangible rewards and these rewards are external to the job or task performed by the employee. External rewards can be in terms of salary/pay, incentives, bonuses, promotions, job security, etc. Intrinsic rewards are intangible rewards or psychological rewards like appreciation, meeting the new challenges, positive and caring attitude from employer, and job rotation after attaining the goal. Frey (1997) argues that once pay exceeds a subsistence level, intrinsic factors are stronger motivators, and staff motivation requires intrinsic rewards such as satisfaction at doing a good job and a sense of doing something worthwhile [3].

And from this consideration, current study will examine whether employee's level of motivation varies with the rewards (both extrinsic and intrinsic) given to them. This study will be beneficial for the managers to know the significance of intrinsic and extrinsic rewards on employee performance and they can work on those sectors to enhance employee performance. Management can get a better idea while developing its reward system as what kind of reward would be given the most importance and at what stage can be known through such a type of study.

The objective of this study is to find out the relationship between rewards and employees' performance. For this study, particularly employees of telecommunication industry of Bangladesh has been selected, and as a sample 81 employees has been taken from four telecommunication companies of Bangladesh, namely, Grameenphone Ltd., Robi Axiata Ltd, Banglalink and Airtel. More specific objectives are to find out:

- The effect of intrinsic rewards on employee's performance.

- The effect of extrinsic rewards on employees' performance and

- Whether intrinsic or extrinsic rewards are the main factor for motivation. 
This paper is organized as follows: after introduction and scope of the study in section 1, literature review is carried out in section 2.Research framework and methodology is mentioned in section 3. Result and discussion is provided in section 4. Final section concludes the study.

\section{Literature Review}

Human resource is the most valuable asset of every organization. In the age of globalization, the workplace realities of previous years no longer exist. The change has been observed on the workplace realities in today's organizations. It is necessary to revise carefully as well as meet and introduce new motivational tools to enhance employee motivation if we want these resources to retain and give their best. Before identifying the rewards that motivate the human resources, we must understand what motivation is.

\subsection{The Meaning of Motivation}

Many contemporary authors have defined the concept of motivation. Motivation has been defined as: the psychological process that gives behavior purpose and direction (Kreitner, 1995)[4]; a predisposition to behave in a purposive manner to achieve specific, unmet needs (Buford, Bedeian, \& Lindner, 1995)[5]; an internal drive to satisfy an unsatisfied need (Higgins, 1994) [6]; and the will to achieve (Bedeian, 1993)[7].

Luthan (1998) defines motivation as, "a process that starts with a physiological deficiency or need that activates a behavior or a drive that is aimed at a goal incentive" [7]. Therefore, the key to understanding the process of motivation lies in the meaning of, and relationship among, needs, drives, and incentives. Relative to this, Minner, Ebrahimi, and Watchel, (1995) state that in a system sense, motivation consists of these three interacting and interdependent elements, i.e., needs, drives, and incentives[8]. According to L. Deckers (2010), Motivation is a person's internal disposition to be concerned with and approach positive incentives and avoid negative incentives [9]. To further this, an incentive is the anticipated reward or aversive event available in the environment.

\subsection{Rewards as Motivational Factor}

Motivated employees are needed in our rapidly changing workplaces. Employees are the sole strategic assets that make organizations alive. To be effective, managers need to understand what motivates employees within the context of the roles they perform. Managers have to play different functions but motivating employees is arguably the most complex. This is due, in part, to the fact that what motivates employees changes constantly (Bowen \& Radhakrishna, 1991) [10].

Organizations can motivate the workforce most through introducing appropriate reward and recognition programs and other benefits. Maire and Nick (2002) referred that, compensation systems deliver other objectives such as legal compliance, labour cost control, perceived fairness towards employees and enhancement of employee performance to achieve high level of productivity and customer satisfaction [11].

Bishop (1987) suggested that, pay is directly related with productivity and reward system depends upon the size of an organization [12]. Firm's reward system plays a critical role in motivating employees to perform creatively . Effective reward and recognition system can be a good motivator but inappropriate reward and recognition program increase de-motivation of the employees.

Reward is the benefit received for performing a task. It is a positive stimulus or incentive that can be presented in the process of reinforcing behavior. According to Decenzo and Robbins (2002), today's workers expect more than just an hourly wage or salary from their employer; they want additional considerations that will enrich their lives. These considerations in an employment setting are called employee benefits [13]. Benefits are the program an employer uses to supplement cash compensation that employee receives.

Rewards can be extrinsic or intrinsic. Extrinsic rewards are the tangible rewards which one gets from the employer. External rewards can be in terms of salary/pay, incentives, bonuses, stock options, promotions, job security, flex-time, etc. Intrinsic rewards are intangible rewards or psychological rewards which one receives from the job itself. These are the self initiated rewards. Such as- pride in one's work, a feeling of accomplishment, appreciation, meeting the new challenges, positive and caring attitude from employer, participation in decision making, or being part of a team.

Rewards may or may not enhance the employee's financial well-being. If they do, they can do this directly through wages, bonuses or profit sharing or indirectly, through employer-subsidized benefits such as retirement plans, paid vacations, paid sick leaves and purchase discounts. Non-financial rewards do not directly increase the employee's financial position but emphasizes on making the life on the job more attractive. Rewards and recognition programs honor both individuals and teams who go the extra mile to service their organizations. 


\subsection{Impact of Rewards on Employees' Motivation (Empirical Review)}

Rewards that an individual receives are very much a part of the understanding of motivation. Carraher et al (2006) advocates that there should be an effective reward system to retain the high performers in the organization and reward should be related to their productivity [14]. A lot of work has been done on evaluating the relationship between rewards and employee motivation and there exist a large number of studies in the literature describing impact of reward on employee motivation. In order to maximize the performance of the employees organization must make such policies and procedures and formulate such reward system under those policies and procedures which increase employee satisfaction and motivation.

Research undertaken by Kovach (1987) suggested that, as employees' income increases, money becomes less of a motivator. Also, as employees get older, interesting work becomes more of a motivator [15].

As an effort to stimulate employees' creativity, many managers have used extrinsic rewards (e.g. monetary incentives) to motivate their employees (Fairbank and William 2001; Van Dijk and Van den Ende, 2002) [16]. While empirical research has shown that extrinsic rewards help enhance individuals' creative performance. Sometimes management pays more attention to extrinsic rewards but intrinsic rewards are equally important for employee motivation. Andrew (2004) concludes that commitment of employees is based on rewards and recognition [17]. Lawler (2003) argued that prosperity and survival of the organizations is determined through how they treat their human resources. It also depends on how they communicate their rewards and recognition programs to their employees and whether these rewarding strategies are clear to the employees [18]. Employee motivation can be increased not only by imposing a single factor; rather it can be enhanced by the combination of several factors.

In the study carried out by Jibowo (1977) on the effect of motivators and hygiene on job performance among a group of 75 agricultural extension workers in Nigeria. The study basically adopted the same method as Herzberg et al. (1959) and it supports the influence of motivators on job performance [19].

In another study carried out by Centres and Bugental (1970), they also base their research on Herzberg's two-factor theory of motivation, which separated job variables into two groups: hygiene factors and motivators. They made use of a sample of 692 subjects to test the validity of the two factor theory. And it was discovered that at higher occupational level, "motivators" or intrinsic job factors were more valued, while at lower occupational levels "hygiene factors" or extrinsic job factors were more valued. From this work they concluded that an organization that satisfies both intrinsic and extrinsic factors of workers get the best out of them [20].

Egwuridi (1981) also investigated motivation among Nigerian workers using a sample of workers of high and low occupational levels. The hypothesis that low income workers will be intrinsically motivated was not confirmed, and the expectation that higher income worker will place a greater value on intrinsic job-factors than low income workers was also not confirmed. This shows clearly the extent of value placed on extrinsic job factors [21].

Nwachukwu (1994) found the productivity of Nigerian workers depend on several factors, among them is employer's failure to provide adequate compensation and the indiscipline of the privileged class that arrogantly displays their wealth, which is very demoralizing to working class and consequently reduced their productivity [22]. Judging from all these empirical research and findings, one may generally conclude that a good remuneration package, which ties financial rewards to individual performance, can be expected to result in higher productivity.

\subsection{Research and Questionnaire Design}

\section{Research Design and Methodology}

As this study tries to recognize the rewards that have impact on employees most in the workplace, the employees (from different age groups, genders, education backgrounds, income level and designations) from the four selected Telecommunication companies of Bangladesh have been taken as population. Employee motivation is taken dependent variable and reward is taken as independent variable. The survey was conducted on September to October 2013 by using convenience method of sampling and 81 questionnaires were distributed among the employees.

The questionnaire was designed to determine employee perception about reward practice and to identify whether intrinsic or extrinsic rewards are more motivational to them. To make the questionnaire understandable, it was divided into three parts. The first part of the questionnaire contained questions regarding employee profile. The questions were designed with multiple-choice selections for convenience. The second part contained questions regarding variables that motivate employee performance. And the third segment was about organization's reward and recognition system. Here, a five point Likert Scale ranging from 1 (strongly disagree) to 5 (strongly agree) was used to measure responses. The answer of the questionnaire is solely based on the respondents` experience and personal opinion. 


\subsection{Framework of the Factors}

As the study focuses on understanding employee motivation in the telecommunication industry of Bangladesh, various intrinsic and extrinsic factors which donate the employee motivation are taken into consideration. The framework of the study is given in Figure 1, 2 and 3 respectively.

Figure 1: Extrinsic Rewards and Employee Motivation

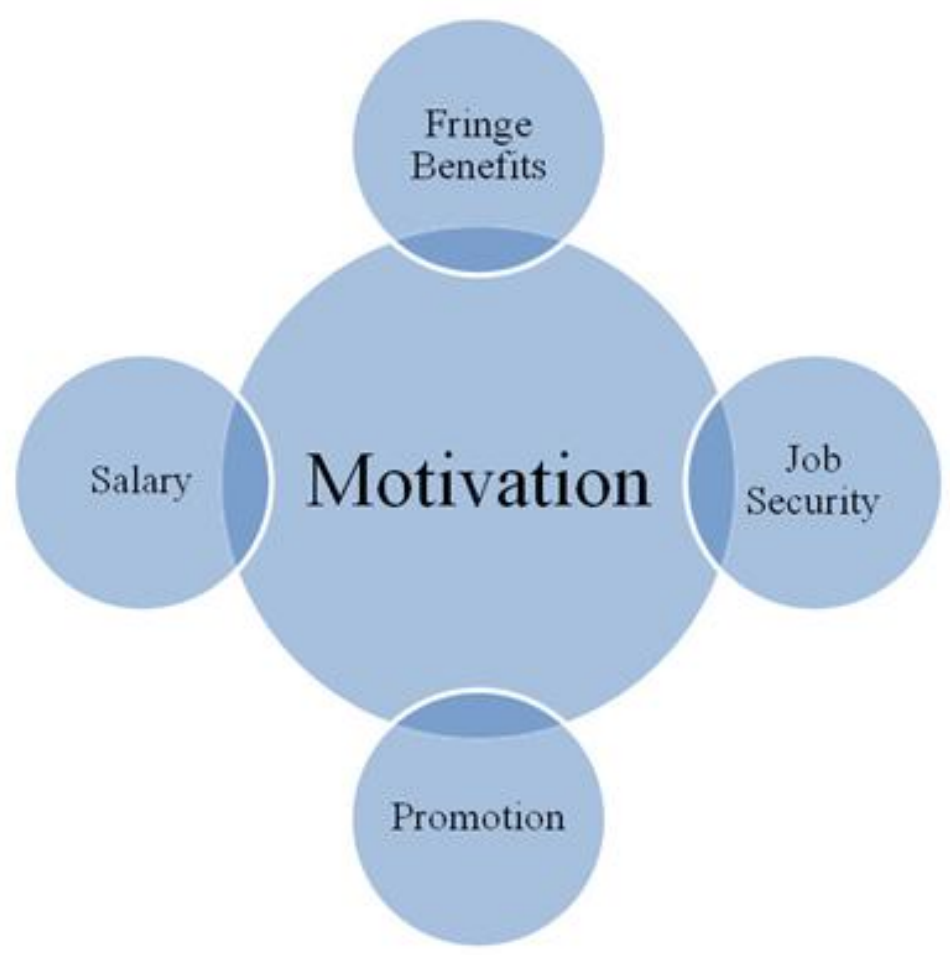

Figure 2: Intrinsic Rewards and Employee Motivation

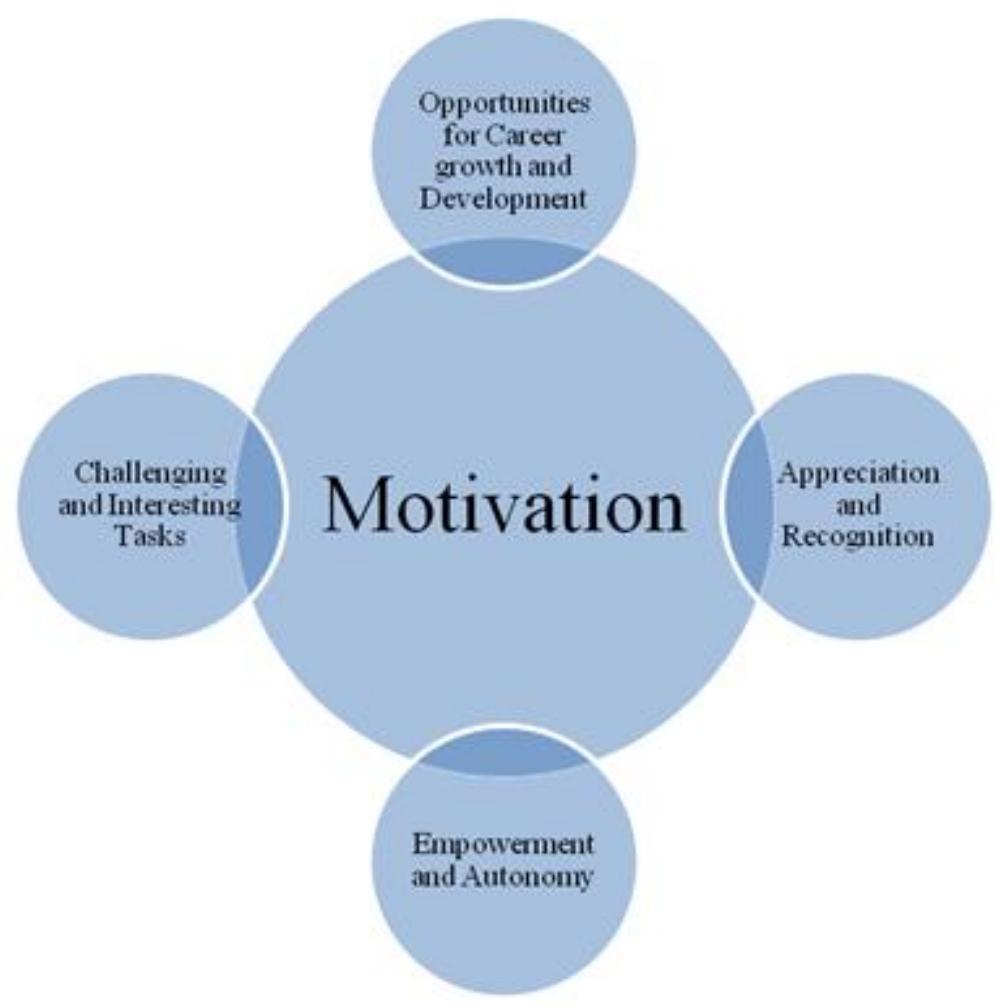


Figure 3: Research Framework

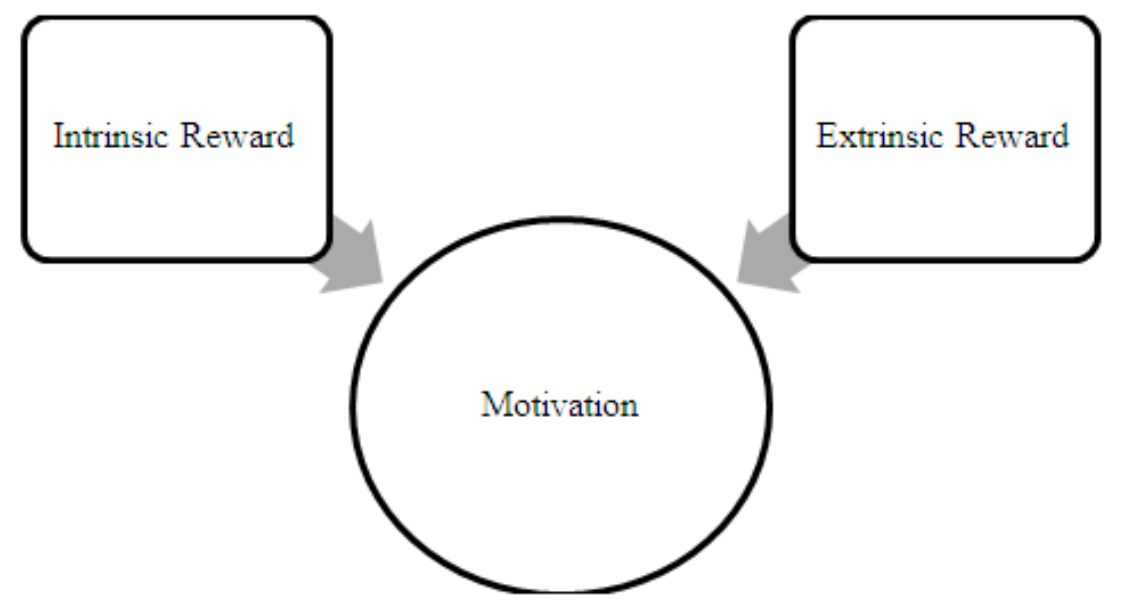

\subsection{Statistical Tools for Data Analysis}

Primary data collected from field survey were tabulated using Microsoft Office Excel, and all data were recorded using numerical codes. Various statistical measures such as frequency distribution, percentage table, mean and standard deviation were used in describing the variables.

\section{Data Analysis and Findings}

This paper has considered some important demographic information, among those- gender, age, years of experience, designation and salary are considered. Respondents' ages lie within 25 to 45 years. Average age is 31.21 years. The demographic characteristics also show a gender division of the respondents, majority of the respondents are males, i.e. $74 \%$ representing a bigger part of the sample group. However, $26 \%$ percent of the respondents are female. $33.33 \%$ of the employees earned between Tk. 55000 - Tk. 100000. Length of service of most of the respondents (40.74\%) is between 3-6 years. Table 1 shows the demographic information of the respondents.

Table 1: Personal profile of the respondents $(\mathrm{N}=81)$

\begin{tabular}{|c|c|c|c|c|}
\hline Profile & Frequency & Percentage & Valid Percentage & $\begin{array}{l}\text { Cumulative } \\
\text { Percentage }\end{array}$ \\
\hline \multicolumn{5}{|l|}{ Gender } \\
\hline Male & 60 & 74.07 & 74.07 & 74.07 \\
\hline Female & 21 & 25.93 & 25.93 & 100.0 \\
\hline \multicolumn{5}{|l|}{ Age } \\
\hline 25-29 Years & 34 & 41.98 & 41.98 & 41.98 \\
\hline 30-34 Years & 35 & 43.21 & 43.21 & 85.19 \\
\hline 35-39 Years & 8 & 9.87 & 9.87 & 95.06 \\
\hline $40-45$ Years & 4 & 4.94 & 4.94 & 100.0 \\
\hline \multicolumn{5}{|c|}{ Years of Experience } \\
\hline 0-3 Years & 11 & 13.58 & 13.58 & 13.58 \\
\hline 4-6 Years & 33 & 40.74 & 40.74 & 54.32 \\
\hline 7-10 Years & 29 & 35.8 & 35.8 & 90.12 \\
\hline 10 Years or above & 08 & 9.88 & 9.88 & 100.0 \\
\hline \multicolumn{5}{|l|}{ Salary in BDT } \\
\hline Below 20000 & 2 & 2.47 & 2.47 & 2.47 \\
\hline $20000-35000$ & 17 & 20.99 & 20.99 & 23.46 \\
\hline $35000-55000$ & 28 & 34.57 & 34.57 & 58.03 \\
\hline $55000-100000$ & 26 & 32.10 & 32.10 & 90.13 \\
\hline 100000 or Above & 8 & 9.87 & 9.87 & 100.0 \\
\hline
\end{tabular}

\subsection{Rewards as an Effective Tool for Employee Motivation in the Workplace}

To identify the relationship between rewards (intrinsic or extrinsic) and motivation of employees in the workplace, 08 attributes have been selected. The descriptive analysis of those variables by showing means and the standard deviations are depicted in Table 2.

Table 2: Descriptive Statistics of the factors (intrinsic and extrinsic rewards)

\begin{tabular}{|l|l|l|l|}
\hline Variables & Mean & Std. Deviation & Ranking \\
\hline Pay (PAY) & 4.4198 & 0.9201 & 8 \\
\hline Fringe benefits (FB) & 4.5129 & 0.8282 & 7 \\
\hline
\end{tabular}




\begin{tabular}{|l|l|l|l|}
\hline Job security (JS) & 4.6296 & 0.6009 & 2 \\
\hline Promotion(PRO) & 4.5802 & 0.7222 & 4 \\
\hline $\begin{array}{l}\text { Challenging and interesting task } \\
\text { (CI) }\end{array}$ & 4.5926 & 0.8482 & 3 \\
\hline $\begin{array}{l}\text { Opportunities for career growth } \\
\text { and development (CG) }\end{array}$ & 4.6419 & 0.7633 & 1 \\
\hline Appreciation and recognition(AR) & 4.5308 & 0.7919 & 6 \\
\hline Empowerment and autonomy(EA) & 4.5556 & 0.7583 & 5 \\
\hline
\end{tabular}

Table 2 explains that majority of the respondents considered "opportunities for career growth and development" (79.01\% respondents) as the main factor for motivating them, whereas "Pay" as the least important factor of motivation. Since employee retrenchment was a significant issue while conducting the survey, mean value of the factor "job security" shows it is the second most prioritized factor according to the respondents (table 2 ).

According to the analysis of mean values of survey data, it is found that, as the years of experience as well as age of the employee increases (level of designation also changes), "pay" becomes less of a motivator. It is also true for the employees of different age groups. This conclusion also supports some other research (Kovach 1987). Significance of the factor "challenging and interesting tasks" also varies with the change of the years of experience as well as age group (Designation). This study also proves this condition. Here this factor is highly supported by the age group 39-40 and by highest level of experienced segment of respondents (table 3 and 4).

Table 3: Impact of rewards on employee motivation (Age group)

\begin{tabular}{|l|l|l|l|l|l|l|l|l|}
\hline $\begin{array}{l}\text { Variables } \\
\text { Age Group) }\end{array}$ & PAY & FB & JS & PRO & CI & CG & AR & EA \\
\hline $25-29$ & 4.4848 & 4.5958 & 4.7419 & 4.7677 & 4.6061 & 4.5152 & 4.5455 & 4.4545 \\
\hline $30-34$ & 4.7576 & 4.6667 & 4.6364 & 4.8909 & 4.4243 & 4.7879 & 4.6667 & 4.6363 \\
\hline $35-39$ & 4.5 & 4.6587 & 4.5125 & 4.8889 & 4.875 & 4.5 & 4.0 & 5.0 \\
\hline $40-45$ & 2.4286 & 4.5682 & 4.4287 & 4.6709 & 5 & 4.5714 & 4.4286 & 4.4285 \\
\hline
\end{tabular}

Table 4: Impact of rewards on employee motivation (years of experience)

\begin{tabular}{|l|l|l|l|l|l|l|l|l|}
\hline \begin{tabular}{l} 
Variables $\begin{array}{l}\text { Cears } \\
\text { Experience) }\end{array}$ \\
\hline $0-3$
\end{tabular} & PAY & FB & JS & PRO & CI & CG & AR \\
\hline $4-6$ & 4.4545 & 4.3636 & 4.5419 & 4.5454 & 4.6364 & 4.3636 & 4.3636 & 4.0 \\
\hline $7-10$ & 4.5151 & 4.6060 & 4.1364 & 4.5454 & 4.4242 & 4.5758 & 4.6061 & 4.6667 \\
\hline 10 years and above & 4.6897 & 4.6587 & 4.0125 & 4.6206 & 4.6896 & 4.8276 & 4.4483 & 4.6862 \\
\hline
\end{tabular}

Career growth and development is also supported by the respondents as one of the major factors for enhancing motivation and as the experience level of the respondents increases, their urge for development increases (table 4). Employees want autonomy and want to be empowered and this need increases with the increase in the years of experience.

Study also reveals that, with the increase in the years of experience, age and income level, employees tend to be motivated intrinsically rather than extrinsically. This finding also proves some previous research (Egwuridi, 1981) (Table 4 and 5).

Table 4: Comparison of motivation level by giving rewards (Years of experience)

\begin{tabular}{|l|l|l|l|l|}
\hline Variables & $\begin{array}{l}\text { Years } \\
\mathbf{0 - 3}\end{array}$ & $\begin{array}{l}\text { Years } \\
\mathbf{4 - 7}\end{array}$ & $\begin{array}{l}\text { Years } \\
\mathbf{8 - 1 0}\end{array}$ & $\begin{array}{l}\text { Years } \\
\mathbf{1 0} \text {-above }\end{array}$ \\
\hline Intrinsic Rewards & 3.4839 & 4.7576 & 5 & 4.4285 \\
\hline Extrinsic Rewards & 4.5484 & 4.3333 & 3.75 & 3.2857 \\
\hline
\end{tabular}

Table 5: Comparison of motivation level by giving rewards (Income level)

\begin{tabular}{|l|l|l|l|l|l|}
\hline Variables & Below Tk. 20000 & $\begin{array}{l}\text { Tk. 20000-Tk. } \\
\text { 35000 }\end{array}$ & $\begin{array}{l}\text { Tk. 35000-Tk. } \\
\text { 55000 }\end{array}$ & $\begin{array}{l}\text { Tk. 55000-Tk } \\
\mathbf{1 0 0 0 0 0}\end{array}$ & $\begin{array}{l}\text { Tk. 100000 and } \\
\text { above }\end{array}$ \\
\hline Intrinsic Rewards & 4.00 & 3.5333 & 4.3181 & 4.4167 & 4.8571 \\
\hline Extrinsic Rewards & 5.00 & 4.6875 & 4.1428 & 4.125 & 3.7142 \\
\hline
\end{tabular}

So it can be said that, "whether employees find intrinsic rewards or extrinsic rewards more motivational', this concept has changed with the change in the income level, level of experience and age group of the respondents. Managers must have to think about giving extrinsic rewards properly like- they must give equal opportunity to employees by their performance. Until employees are satisfied with their extrinsic rewards, they would not be satisfied with intrinsic rewards like- challenging tasks or appreciation etc. 


\subsection{How Telecommunication Industry of Bangladesh is performing in Motivating Employees (Employees' Viewpoint)}

Employees become motivated most if they get ample opportunities for growth and development. From the survey, it is found that, maximum respondents, i.e., $82.72 \%$ agreed they are "well aware of what is expected from their work" and $62.96 \%$ of the respondents responded that they are given "opportunity to do their best". That is their company is well aware of this factor and giving enough opportunity for their growth and development. Whereas, maximum respondents i.e. $60.49 \%$ answered they feel that their organization is performing above average in building a spirit of teamwork and cooperation among coworkers. Whereas, $34.57 \%$ of the employees feel their organization is doing extremely well in this sector. Telecommunication companies in Bangladesh should be concerned about increasing the harmonious relationship among the employees at workplace.

Study reveals that, employees want to be promoted to the next level on the basis of performance. They also want active participation in decision making. But the fact is majority (i.e. $51.85 \%$ in this study) of the respondents neither agreed nor disagreed on the fact that their respective organizations are giving the "ample opportunities to grow" and $29.63 \%$ of them strongly agreed with it. $49.38 \%$ of the respondents neither agreed nor disagreed that their "opinions are considered" at workplace whereas $48.15 \%$ of them strongly agreed with this statement. From these statistics, it can be said that, organizations should give much of their concern on employees' career progression. However, they are doing well in engaging employees on decision making. Maximum employees feel that their respective organizations must provide challenging and creative tasks to them.

Another employee motivational technique for the organizations is giving "value and appreciation "to the work of the employees. But the true picture is $58.02 \%$ of the respondents experienced their organization is doing above average in demonstrating the employees' "work is valued and respected". Whereas, $29.63 \%$ of them find that their organization is performing well in this factor.

Organizations should provide a road map to the employees from which they understand what their respective organizations precisely want from them. Maximum numbers of employees (67.5\%) are neither satisfied nor dissatisfied with their current reward and recognition programs offered by their organizations. Telecommunication companies must consider improvement in this sector.

\subsection{The Overall Satisfaction with the Current Motivational Programs of the Organizations}

$67.5 \%$ of the respondents are neither satisfied nor dissatisfied with the present motivational factors adopted by their respective organizations, whereas, $25 \%$ of the respondents are not at all satisfied and only rest $7.5 \%$ of them are very satisfied with the current motivational factors.

Figure 4: Graphical representation of the overall satisfaction with the current motivational programs.

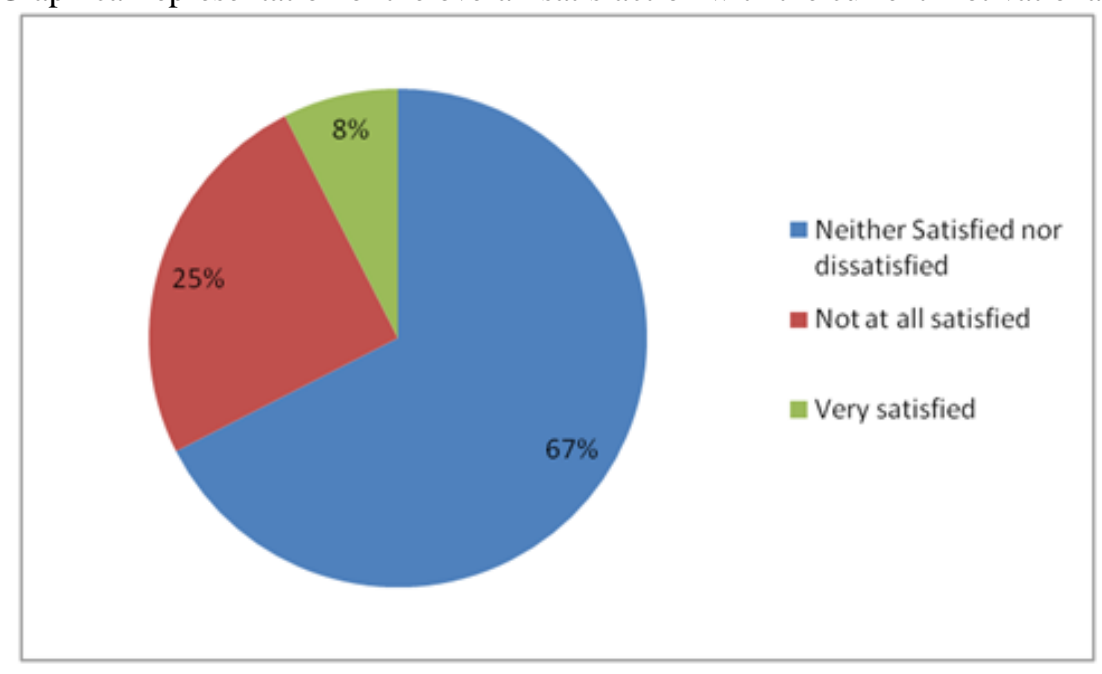

\section{Recommendation and Conclusion}

Human resource is the most important asset of every organization. Acquiring and retaining these resources is one the major challenges faced by many organizations. The results from the study reveal that telecommunication companies in Bangladesh are performing exceptionally well in motivating their workforce and they provide competitive remuneration. However, there are some problems that should be taken care of- 
- Remuneration is important but it is not the single most important factor for motivating employees. There are some other important factors that could motivate employee performance. Still, it should be fair enough and transparent.

- Telecom companies must have to ensure both extrinsic and intrinsic rewards if they want to improve and develop their employee's performances.

- Organizations should create opportunities for employee growth and development.

- Create opportunities for employees to work with teams and increase the employee cooperation. It might seem logical for companies to offer team rewards instead of individual to foster team spirit, but they should not emphasize on team achievement at the cost of individual achievement. Therefore it should be done both ways covering the individuals and the team as a whole too.

- Management should encourage employees to participate in decision making and promotion should be given on the basis of performance.

- Flex-time should be considered as important criterion for enhancing employee motivation.

- The companies need to maintain work life balance of the employees in order to motivate them to perform better.

- Employees need to know that their contributions are noticed, valued and part of expanding the enterprise.

- Verbal praises and recognitions for the works done should never be denied to the employees.

- Cross-border job opportunities should be provided to boost up employee motivation.

- Every year a number of employees should be selected on the basis of their performance and talents for further development. They should be treated as key assets for their company.

From this study it can be inferred that it is not just one factor, for example it is not just monetary rewards which motivate an employee, though monetary compensation is the physiological factor to the employees. This essentially says that the employees need to be motivated with the content of their job. That is the employees in any organization need to be constantly provided with opportunities for learning new skills so that they do not feel monotonous. They should be motivated to use the acquired skills on their job. The organizations need to provide challenging opportunities to the employees. The organizations also should emphasize on work life balance, and should provide options to employees, like- flextime, day care centre for their children etc. They must be encouraged to participate in decision making and they need to get challenging tasks. The employees would appreciate these initiatives. It is important to link pay to performance as it is an effective motivator when people know what they are going to get in return for certain efforts or achievements, and when they feel that what they may get is worth having.

There are certain limitations of the study which can be taken into account for further studies in the future, like sample size was too small and only telecommunication sector was considered.

\section{References}

[1]. Baron, R. A, Behavior in organizations (Allyn \& Bacon, Inc., New York,1983)

[2]. Bowen, R. Brayton, Recognizing and Rewarding Employees (McGraw Hill, New York, 2000).

[3]. Frey. B., On the Relationship between Intrinsic and Extrinsic Work Motivation, International Journal of Industrial Organization, 15,

[4]. $1997, \mathrm{p} 427-439$.

[5]. Kreitner, R., Management (6th ed.) (Houghton Mifflin Company, Boston s1995).

[6]. Buford, J. A., Jr., Bedeian, A. G., \& Lindner, J. R., Management in extension (3rd ed.) (Columbus, Ohio: Ohio State University Extension, 1995).

[7]. Higgins, J. M., The management challenge (2nd ed.) (Macmillan, New York, 1994)

[8]. Bedeian, A. G., Management (3rd ed.) (New York: Dryden Press, 1993).

[9]. Luthans, F., Organisational Behaviour. 8th ed.( Boston: Irwin McGraw-Hill. McCormick, 1998).

[10]. Miner, J.B., Ebrahimi, B., \& Wachtel, J.M., How deficiency in management contributes to the United States' competiveness problem and what can be done about it? Human Resource Management. Fall, 1995, pp. 363

[11]. Deckers, L. (2010). Motivation; Biological, Psychological and Environmental.(3rd ed., pp. 2-3). MA: Pearson, Boston.

[12]. Bowen, B. E., \& Radhakrishna, R. B., Job satisfaction of agricultural education faculty: A constant phenomena. Journal of Agricultural Education, vol. 32, No. 2, 1991, PP. 16-22.

[13]. Maire, K. and Nick, O., Collective and Individual Improvement Activities: the Role of Reward Systems, Personal Review, 2002, PP.320-337.

[14]. Bishop, J., The recognition \& Reward of Employee Performance, Journal of Labor Economics, Vol. 5, No. 4 Part 2: The New Economics of Personnel, 1987, pp.313-351.

[15]. Robbins, S.P. and Decenzo, D. A., Human resource management (John Wiley \& Sons, Inc., New York, 2002

[16]. Carraher, R, Gibson, A. \& Buckley R., Compensation in the Baltic and the USA, Baltic Journal of Management Vol. 1, 2006, pp 7-23.

[17]. Kovach, K. A., What motivates employees? Workers and supervisors give different answers, Business Horizons, Vol. 30, . 1987,PP. 58-65.

[18]. Fairbank, J.F., and Williams, S.D, Motivating Creativity and Enhancing Innovation through Employee Suggestion System Technology, Creativity and Innovation Management, Vol.10. No.2, 2001, pp. 68-74.

[19]. Andrew, D and Kent, R., The impact of perceived leadership behaviors on satisfaction, commitment, and motivation: An expansion of the multidimensional model of leadership, International Journal of Coaching Science, Vol. 1, No. 1, 2007, pp. 35-56. 
[20]. Lawler, E. E., Treat people right( Jossey-Bass Inc., McGraw-Hill Irwin, San Francisco, 2003).

[21]. Jibowo, A.A., Effect of motivators and hygiene factors on job performance among extension workers in the former Western State of Nigeria, The Quarterly Journal of Administration, 12 (1), 1977, pp. 45-54.

[22]. Centres and O, Bugental., Intrinsic and Extrinsic Job motivators among different segments of the working population, Journal of Applied Psychology, 50, 1970, pp 193-197.

[23]. Egwuridi, P.C., Job Satisfaction: Effects on Job Characteristics. Unpublished MSc Dissertation University of Lagos, Nigeria, 1981.

[24]. Nwackukwu, C.C., Effective leadership and productivity. Evidence from a national survey of industrial organization, African Journal for the Study of Social Issues, 1, 1994, pp. 38-46 